\title{
Angiosperm Checklist of Espírito Santo: using electronic tools to improve the knowledge of an Atlantic Forest biodiversity hotspot
}

\author{
Valquíria Ferreira Dutra ${ }^{1}$, Anderson Alves-Araújo ${ }^{2} \&$ Tatiana Tavares Carrijo ${ }^{3}$
}

\begin{abstract}
A checklist of angiosperm species for the state of Espírito Santo, Brazil is presented. A total of 6,204 native species was recorded, representing an increase of $16 \%$ in species richness for the area. Espírito Santo shelters $32 \%$ of the native species of Brazil's Atlantic Forest and holds 516 endemic species $(8.3 \%$ of the total registered taxa for the State). Bromeliaceae and Orchidaceae are the families with highest number of endemic species (142 spp. and 80 spp., respectively), followed by Myrtaceae (33 spp.), Melastomataceae (30 spp.), and Araceae (23 spp.). This paper represents an important landmark for future research in plant diversity in Espírito Santo, and highlights the importance of consulting online databases in order to update the knowledge presented by the Brazilian flora checklist.
\end{abstract}

Key words: Brazil, endemism, floristics, species richness, virtual herbarium.

\begin{abstract}
Resumo
Uma listagem de angiospermas do estado do Espírito Santo é apresentada, incluindo um total de 6.204 espécies nativas, representando um aumento de $16 \%$ na riqueza de espécies registrada para o Estado. O Espírito Santo abriga 32\% das espécies nativas da Floresta Atlântica e apresenta 516 espécies endêmicas (8.3\% do total registrado para o Estado). As famílias Bromeliaceae e Orchidaceae apresentam o maior número de espécies endêmicas (142 spp. e 80 spp., respectivamente), seguidas por Myrtaceae (33 spp.), Melastomataceae (30 spp.) e Araceae (23 spp.). Os resultados representam um importante marco para futuras pesquisas em diversidade de plantas no Espírito Santo e destacam a importância de consultar as plataformas virtuais para atualização da Lista de Espécies da Flora do Brasil.

Palavras-chave: Brasil, endemismo, flora, herbários virtuais, riqueza de espécies.
\end{abstract}

\section{Introduction}

The Brazilian Atlantic Forest is one of the richest biogeographic zones for plant species and endemism in the world (Prance 1982; Mittermeier et al. 1999; Tabarelli et al. 2004). The high number of endemic species, together with the accelerated habitat loss, places this biome among the 35 biodiversity hotspots of the world (Myers et al. 2000; Mittermeier et al. 2005), justifying a higher conservation priority. Centuries of deforestation have led to the reduction of this biome's original cover to $11.4-16 \%$, resulting in forest fragmentation, with most fragment sizes smaller than 50 ha (Ribeiro et al. 1999). This is of major concern, because species richness can be strongly affected by the size and shape of remnants, the degree of connectivity among them and by land use history (Metzger 2003).

Espírito Santo is one of Brazil's richest states in terms of angiosperm species. The state has an area of approximately $45,600 \mathrm{~km}^{2}$, which was originally completely covered by Atlantic Forest (MMA 2000). The different vegetation types comprise ombrophyllous and semideciduous forests, swamps, 'restingas' (coastal lowland formations), mangroves, and vegetation refuges (MMA 2000; Pereira 2007). There are two main geological zones in the state: a central-southern

\footnotetext{
${ }^{1}$ Universidade Federal do Espírito Santo, Depto. Ciências Biológicas, CCHN, Av. Fernando Ferrari 514, Goiabeiras, 29075-910, Vitória, ES, Brazil. valquiriafdutra@gmail.com

${ }^{2}$ Universidade Federal do Espírito Santo, Depto. Ciências Agrárias e Biológicas, CEUNES, Rodovia BR 101 Norte, Km 60, Litorâneo, 29932-540, São Mateus, ES, Brazil.sapotae@gmail.com

${ }^{3}$ Universidade Federal do Espírito Santo, Depto. Biologia, CCA, Alto Universitário s.n., 29500-000, Alegre, ES, Brazil. tcarrijo@gmail.com
} 
montane region reaching 2,000 $\mathrm{m}$ above sea level, comprising deep valleys with open ombrophyllous and upper montane forests, and a 'tabuleiro' (tabletop mountain) zone in the central-northern region. The vegetation of the latter ranges from 'restinga' to dense ombrophyllous forests (IPEMA 2005). Espírito Santo is included in the 'Corredor Central da Mata Atlântica' (Aguiar et al. 2005), one of the main regions of plant endemism in Brazil (Prance 1982; IPEMA 2005).

According to the Brazil Flora Group (BFG 2015) the angiosperm diversity estimated for Espírito Santo comprises about $16.5 \%$ of the total species richness in Brazil, with an estimated 32,109 taxa. Amongst these species, many are restricted and currently assigned as threatened (BFG 2015; Martinelli \& Moraes 2013). Despite the existence of some floristic studies carried out in the last three decades (e.g. Peixoto \& Gentry 1990; Fabris \& César 1996; Pereira \& Zambom 1998; Pereira et al. 1998; Pereira \& Araújo 2000; Assis et al. 2004; Fraga et al. 2007; Fabris \& Peixoto 2013; Chagas et al. 2014; Saiter \& Thomaz 2014; Sarnaglia Junior et al. 2014; Pertele et al. 2015), the species richness recorded to this state continues to be less well known than what is found for its neighboring states, whose floras are published in print or on the internet: Rio de Janeiro (<http://florariojaneiro.jbrj. gov.br/consulta.php>), São Paulo (Wanderley et al. 2011), and some regional floras within Minas Gerais (Giulietti et al. 1987; Pirani et al. 2003). To date, the best compilation of plant species richness in ES is supplied by the Brazilian List of Plants and Fungi, henceforth Brazilian List (BFG 2015).

The Brazilian List was continuously updated until early 2015 through a digital online platform. This database lists species information such as correct and accepted names and synonyms documented through vouchers or bibliographical references, habit, substrate and vegetation type, geographic distribution and endemism searchable fields. The INCT - Virtual Herbarium of Flora and Fungi (HVFF) launched through the SpeciesLink platform in 2009 (CRIA 2014), provides free and open access data and information regarding Brazilian plant collections. Together, these databases have become one of the most important tools for Brazilian researchers in plant taxonomy, and an important source of information for the development of the 'Flora do Espírito Santo' project. This project aims to provide support for the establishment of regional plant family monographs in accordance with the Updated Global Strategies of Plant Conservation 2011-2020 (GSPC-CDB).

Considering the inconsistencies found between the Brazilian List and the HVFF databases: 1. voucher specimens (identified by experts) in herbaria bearing species names not found in the Brazilian List; 2. species listed as occurring in Espírito Santo in the Brazilian List without vouchers in the HVFF database; this study aimed to find and to correct inconsistencies between the two databases, in order to provide a more complete list and an accurate estimate of angiosperm species number in Espírito Santo.

\section{Methods}

The Espírito Santo State (ES) is located in Southeastern Brazil, bordering with Minas Gerais, Bahia, and Rio de Janeiro states (Fig. 1). A combination of two main databases, the Brazilian List (BFG 2015) and the INCT - Virtual Herbarium (HVFF, <http://inct.splink.org.br/>), was used to prepare the checklist. In the first instance, a filtered list of angiosperm species that occur in ES was requested from the Brazilian List project coordination. This initial list consisted of 5,304 records (subfamilies, infraspecific taxa, and hybrids were not included). Each record was checked against the INCT Virtual Herbarium database, where herbarium specimen data can be searched by using relevant parameters such as taxon name, geographical distribution, collector name and number. Therefore, a list of species (taxon name) that occur in a particular geographic location (a Brazilian state or municipality - ES in this case) can easily be accessed, and includes information about the hosting herbaria, identification authorship

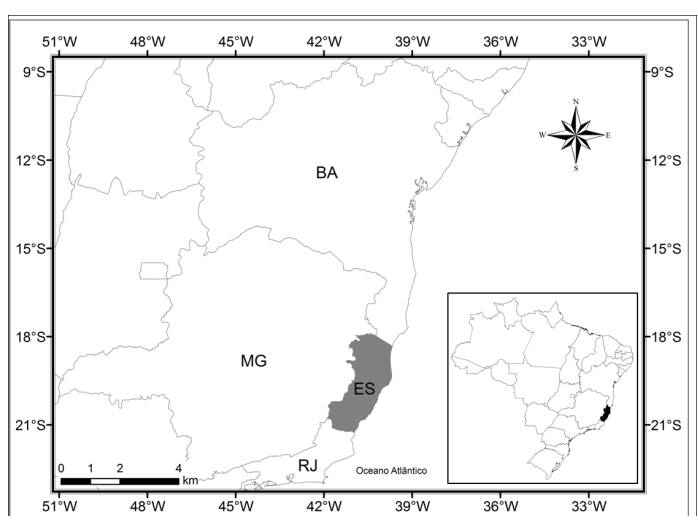

Figure 1 - Location of Espírito Santo State, Brazil. 
and date. We performed intensive and extensive exploration analyses covering all vouchers accessible at the HVFF database. Vouchers with provenance from ES and identified by specialists were prioritized, replacing the vouchers listed by the contributors to the Brazilian List, when these were not from ES. When a particular ES collected record could not be tracked for a given taxon name, the voucher cited in the Brazilian List was maintained. For vouchers listed in the Brazilian List that were not included in the HVFF, literature sources were added.

In order to expand the available information, specific bibliography comprising species records from ES was searched. Taxonomic revisions and scientific articles that report new species from ES and published in the last 10 years were included in the search using the scientific literature databases ISI $(<\mathrm{http}: / /$ wokinfo.com/>), SCOPUS (<http://www. scopus.com/home.url $>)$, Google Scholar $(<\mathrm{http} / / /$ scholar.google.com.br/>), 'Portal de Periódicos CAPES' (<http://www.periodicos.capes.gov.br/>) and JSTOR $(<\mathrm{http}: / /$ www.jstor.org/ $>)$.

Species were listed alphabetically by family and genus (circumscription following APG (2009)), indicating endemic species $(\bullet)$ and new records $(*)$ to BFG (2015). Cultivated and species naturalized were highlighted by (!) and (+), respectively. Herbaria acronyms follow Index Herbariorum (Thiers, continuously updated).

\section{Results}

The revised Angiosperm list from ES comprises 6,364 species belonging to 1,390 genera and 180 families (see supplementary material $<$ http://dx.doi.org/10.6084/m9.figshare.1613856> - DOI: 10.1590/2175-7860201566414) which 6,204 are native, 74 are cultivated, and 110 are naturalized.

The richest families (Fig. 2) are Orchidaceae (744 spp.), Bromeliaceae (386 spp.), Fabaceae (384 spp.), Asteraceae (291 spp.), Myrtaceae (291 spp.), Rubiaceae (239 spp.), Melastomataceae (197 spp.), Apocynaceae (175 spp.), Cyperaceae (175 spp.) and Poaceae (174 spp.). The five richest genera are Solanum L. (Solanaceae - 96 spp.), Eugenia L. (Myrtaceae - 95 spp.), Vriesea Lindl. (Bromeliaceae - 88 spp.), Myrcia DC. (Myrtaceae - 81 spp.), and Piper L. (Piperaceae - 74 spp.).

According to the results obtained, there are 516 species endemic to Espírito Santo. Furthermore, ES houses $8.3 \%$ of the all endemic species

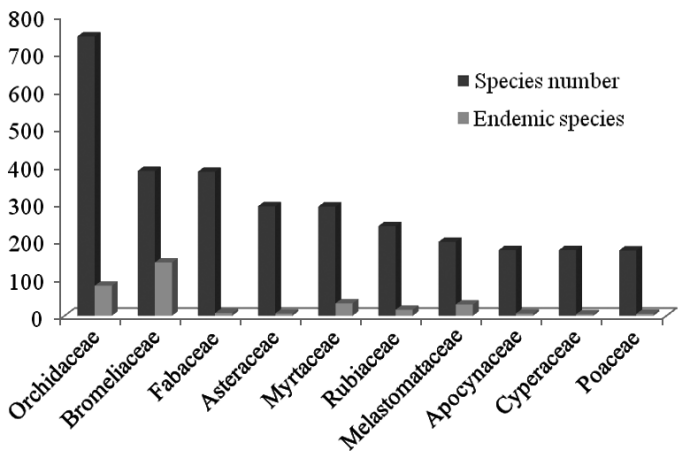

Figure 2 - Richest angiosperm families and their endemic species numbers from the state of Espírito Santo.

registered for Brazil and 7.4\% of all Atlantic Forest species. Bromeliaceae and Orchidaceae include the highest number of endemic species for the state (142 spp. and 80 spp., respectively), followed by Myrtaceae (33 spp.), Melastomataceae (30 spp.), and Araceae (23 spp.) (Fig. 2). Cryptanthus Otto \& A.Dietr. and Alcantarea (E.Morren ex Mez) Harms (Bromeliaceae) showed the highest percentage of endemic species with $81 \%$ and $75 \%$, respectively.

Several common widespread taxa were not listed in the BFG (2015) as occurring in Espírito Santo, e.g. Gallesia integrifolia (Phytolaccaceae), Microsthachys bidentata (Mart. \& Zucc.) Esser (Euphorbiaceae), and Cucumis anguria L. (Cucurbitaceae), despite their wide distribution throughout Brazil. Other examples are Chomelia oligantha Müll.Arg. (Rubiaceae) and Agarista eucalyptoides (Cham. \& Schltdl.) G.Don (Ericaceae) that occur in adjacent areas of the bordering states of Bahia, Minas Gerais and Rio de Janeiro and were found to occur in ES. In addition, many examples of species first recorded for the Atlantic Forest represent new cases of disjunction between it and the Amazon Forest, such as Crepidospermum rhoifolium (Benth.) Triana \& Planch (Burseraceae), and Fridericia patellifera (Schlecht.) L.G. Lohmann, the latter previously recorded for the Amazon Forest, Cerrado and Pantanal biomes. Furthermore, the known geographically distribution of a larger number of species was expanded by being recorded in ES (Appendix 1).

\section{Discussion and conclusion}

With an increase of 900 species over the number recorded for ES by the BFG (2015), the 
present results suggest that ES is no longer the tenth state in species richness in the country (BFG 2015) but in reality it occupies the seventh position, overtaking the states of Goiás, Mato Grosso and Paraná. A simple area comparison makes it obvious that the ES is amongst the richest states in terms of plant diversity in Brazil, with a relatively small area (23rd amongst Brazilian states with an area of $46.096,925 \mathrm{~km}^{2}$ ) harbouring extremely high number of species. The state's plant richness has already been highlighted by Forzza et al. (2012) who stated that it holds $32 \%$ of the angiosperm richness from the Atlantic Forest. The number of angiosperm species registered by Fraga et al. (2007) and by the BFG (2015) for the ES were increased here by around $50 \%$ and $16 \%$, respectively. The ranking of the Orchidaceae, Bromeliaceae, Fabaceae and Asteraceae for ES remains very similar to previous results reported for the Atlantic Forest by Stehmann et al. (2009), who reported Fabaceae in second and Bromeliaceae in third place.

Despite the fact that Stehmann et al. (2009) highlight Orchidaceae, the richest family, as having the highest number of endemic species for the Atlantic Forest, partial results shown here for the state show that Bromeliaceae has more records of endemic species than Orchidaceae in ES. In more specific terms, it is known that the Atlantic Forest is the diversity centre of speciose genera such as Alcantarea and Cryptanthus (Martinelli et al. 2008) that are particularly expressive in ES, partially explaining the large number of endemic species for Bromeliaceae in this state.

The complete documentation of the ES flora by the year 2020, in accordance to the goals of the Convention on Biological Diversity and the Global Strategy for Plant Conservation (CBD 2010), represents a big challenge. Geographical gaps in plant collections are notorious despite a reasonably well-scored species per area relationship. Exploration in such poorly-sampled areas is of strategic importance if we are to improve species documentation. In this sense, performing regional inventories is highly recommended to improve the quality of the knowledge of the state and consequently of the Flora of Brazil.

The improvement of floristic knowledge is currently one of the greatest research challenges in Brazil. The present case study in the ES state establishes online plant databases as fundamental tools to record and retrieve species richness information. Considering that there are still many plant collections from Brazil that have not been databased and included in the available virtual herbaria, and that there are parts of the state that are less accessible and presently undercollected, it is most likely that the checklist of angiosperms in ES will need readjustments, with ongoing studies still revealing many further records.

\section{Acknowledgements}

We are grateful to Dra. Rafaela Forzza for supporting and encouraging us from the early stages to the completion of this study; to the coordination and team of the Brazilian List by providing relevant data about ES; to FAPES and $\mathrm{CNPq}$ for financial support of floristic surveys that allowed the collection of material in poorly sampled areas; to Dr. Mário L. Garbin, Dra. Daniela Zappi and two anonymous reviewers for their helpful comments and suggestions.

\section{References}

Aguiar, A.P.; Chiarello, A.G.; Mendes, S.L. \& Matos, E.N. 2005. Os Corredores Central e da Serra do Mar na Mata Atlântica brasileira. In: Galindo-Leal, C. \& Câmara, I.G. (eds.). Mata Atlântica: biodiversidade, ameaças e perspectivas. Fundação SOS Mata Atlântica, Conservação Internacional e Centro de Ciências Aplicadas à Biodiversidade, Belo Horizonte. Pp. 119-132.

Almeida, R.F. \& Mamede, M.C.H. 2014. Checklist, conservation status, and sampling effort analysis of Malpighiaceae in Espírito Santo State, Brazil. Brazilian Journal of Botany: 37: 329-337.

Alves, M. \& Luz, C.L. 2014. Juncaceae. In: Lista de espécies da flora do Brasil. Jardim Botânico do Rio de Janeiro. Available at $<$ http://floradobrasil.jbrj. gov.br/jabot/floradobrasil/FB8084>. Access on 19 June 2014.

Amaral, M.C.E.; Pellegrini, M.O.O. \& Lima, C.T. 2015. Nymphaeaceae. In: Lista de Espécies da Flora do Brasil. Jardim Botânico do Rio de Janeiro. Available at $<$ http://floradobrasil.jbrj.gov.br/jabot/floradobrasil/ FB10937>. Access on 12 October 2015.

APG. 2009. An update of the Angiosperm Phylogeny Group classification for the orders and families of flowering plants: APG III. Botanical Journal of the Linnean Society 161: 105-121.

Araujo, A.O.; Chautems, A. \& Ferreira, G.E. 2014. Gesneriaceae. In: Lista de espécies da flora do Brasil. Jardim Botânico do Rio de Janeiro. Available at $<$ http:/floradobrasil.jbrj.gov.br/jabot/floradobrasil/ FB119>. Access on 19 June 2014.

Barthlott, W. \& Taylor, N.P. 1995. Notes towards a monograph of Rhipsalideae (Cactaceae). Bradleya 13: 43-79. 
Barros, F. de; Vinhos, F.; Rodrigues, V.T.; Barberena, F.F.V.A.; Fraga, C.N.; Pessoa, E.M.; Forster, W.; Menini Neto, L.; Furtado, S.G.; Nardy, C.; Azevedo, C.O. \& Guimarães, L.R.S. 2014. Orchidaceae. In: Lista de espécies da flora do Brasil. Jardim Botânico do Rio de Janeiro. Available at $<$ http://floradobrasil. jbrj.gov.br/jabot/floradobrasil/FB11004>. Access on 28 June 2014.

Baumgratz, J.F.A.; Caddah, M.K.; Chiavegatto, B.; Goldenberg, R.; Guimarães, P.J.F.; Koschnitzke, C.; Kriebel, R.; Lima, L.F.G.; Martins, A.B.; Michelangeli, F.A.; Reginato, M.; Rocha, M.J.R.; Rodrigues, K.F.; Romero, R.; Rosa, P.; Silva-Gonçalves, K.C.; Souza, M.L.D.R. \& Woodgyer, E. 2015. Melastomataceae. In: Lista de Espécies da Flora do Brasil. Jardim Botânico do Rio de Janeiro. Available at $<$ http://floradobrasil. jbrj.gov.br/jabot/floradobrasil/FB161>. Access on 10 October 2015.

BFG. 2015. Growing knowledge: an overview of Seed Plant diversity in Brazil. Rodriguésia 66: 1085-1113.

Bove, C.P. 2014. Cymodoceaceae. In: Lista de espécies da flora do Brasil. Jardim Botânico do Rio de Janeiro. Available at <http://floradobrasil.jbrj.gov.br/jabot/ floradobrasil/FB7145>. Access on 08 June 2014.

Bovini, M.G.; Esteves, G.; Duarte, M.C.; Takeuchi, C. \& Kuntz, J. 2015. Malvaceae. In: Lista de Espécies da Flora do Brasil. Jardim Botânico do Rio de Janeiro. Available at $<$ http://floradobrasil.jbrj.gov.br/jabot/ floradobrasil/FB156>. Access on 10 October 2015.

Bove, C.P. 2015. Ruppiaceae. In: Lista de Espécies da Flora do Brasil. Jardim Botânico do Rio de Janeiro. Available at $<$ http://floradobrasil.jbrj.gov.br/jabot/floradobrasil/ FB211>. Access on 10 October 2015.

Braga, J.M.A. 2015. Menispermaceae. In: Lista de Espécies da Flora do Brasil. Jardim Botânico do Rio de Janeiro. Available at <http:/floradobrasil.jbrj.gov.br/jabot/ floradobrasil/FB85697>. Access on 11 October 2015.

Braga, J.M.A. \& Saka, M. 2015. Marantaceae. In: Lista de Espécies da Flora do Brasil. Jardim Botânico do Rio de Janeiro. Available at $<$ http://floradobrasil.jbrj. gov.br/jabot/floradobrasil/FB36745>. Access on 11 October 2015.

Bittrich, V. 2015. Theaceae. In: Lista de Espécies da Flora do Brasil. Jardim Botânico do Rio de Janeiro. Available at $<$ http://floradobrasil.jbrj.gov.br/jabot/floradobrasil/ FB233>. Access on 10 October 2015.

CBD. 2010. COP 10 Decision X/17: consolidated update of the global dtrategy for plant conservation 2011-2020. CBD. Available at <http://www.cbd.int/decision/ cop/?id=12283>. Access on 20 Sep. 2014.

Chacon, R.G. \& Yamamoto, K. 2014. Ouratea. In: Lista de espécies da flora do Brasil. Jardim Botânico do Rio de Janeiro. Available at $<$ http://floradobrasil.jbrj. gov.br/jabot/floradobrasil/FB19937>. Access on 28 June 2014.

Chagas, A.P.; Peterle, P.L.; Thomaz, L.D.; Dutra, V.F. \& Valadares, R.T. 2014. Leguminosae-Caesalpinioideae do Parque Estadual Paulo César Vinha, Espírito Santo, Brasil. Rodriguésia: 65: 099-112.

Chiron, G. \& Bolsanello, R.X. 2013. As orquídeas da Serra do Castelo (Espírito Santo - Brasil). Vol. 2. Voreppe, Tropicalia. 422p.

Cordeiro, I.; Secco, R.; Cardiel, J.M.; Steinmann, V.; Caruzo, M.B.R.; Riina, R.; Lima, L.R. de; Maya-L., C.A.; Berry, P.; Carneiro-Torres, D.S.; Silva, O.L.M.; Sales, M.F.D.; Silva, M.J. da; Sodré, R.C.; Martins, M.L.L.; Pscheidt, A.C.; Athiê-Souza, S.M.; Melo, A.L.D.; Oliveira, L.S.D.; Paula-Souza, J. \& Silva, R.A.P. 2015. Euphorbiaceae. In: Lista de Espécies da Flora do Brasil. Jardim Botânico do Rio de Janeiro. Available at $<$ http://floradobrasil.jbrj.gov.br/jabot/ floradobrasil/FB113>. Access on 10 October 2015.

CRIA. 2014. INCT - Herbario Virtual das Plantas e Fungos. Available at $<$ http://inct.splink.org.br/index $>$. Access on 29 July 2014.

Dettke, G.A. \& Caires, C.S. 2015a. Loranthaceae. In: Lista de Espécies da Flora do Brasil. Jardim Botânico do Rio de Janeiro. Available at $<$ http://floradobrasil. jbrj.gov.br/jabot/floradobrasil/FB152>. Access on 10 October 2015.

Dettke, G.A. \& Caires, C.S. 2015b. Santalaceae. In: Lista de Espécies da Flora do Brasil. Jardim Botânico do Rio de Janeiro. Available at $<$ http://floradobrasil. jbrj.gov.br/jabot/floradobrasil/FB215>. Access on 10 October. 2015.

Fabris, L.C. \& César, O. 1996. Estudos florísticos em uma mata litorânea no sul do estado do Espírito Santo. Boletim do Museu de Biologia Mello Leitão (Nova Série) 5: 15-46.

Fabris, L.C. \& Peixoto, A.L. 2013. Sapotaceae das restingas do Espírito Santo, Brasil. Rodriguésia 64: 263-283.

Filgueiras, T.S.; Canto-Dorow, T.S.; Carvalho, M.L.S.; Dórea, M.C.; Ferreira, F.M.; Mota, A.C.; Oliveira, R.C. de; Oliveira, R.P.; Reis, P.A.; Rodrigues, R.S.; SantosGonçalves, A.P.; Shirasuna, R.T.; Silva, A.S.; Silva, C.; Valls, J.F.M.; Viana, P.L.; Welker, C.A.D.; Zanin, A. \& Longhi-Wagner, H.M. 2014. Poaceae. In: Lista de Espécies da Flora do Brasil. Jardim Botânico do Rio de Janeiro. Available at $<$ http://floradobrasil.jbrj.gov.br/ jabot/floradobrasil/FB193>. Access on 28 June 2014.

Forzza, R.C.; Baumgratz, J.F.A.; Bicudo, C.E.M.; Canhos, D.A.L.; Carvalho, A.A.; Coelho, M.A.N.; Costa, A.F.; Costa, D.P.; Hopkins, M.G.; Leitman, P.M.; Lohmann, L.G.; Lughadha, E.N.; Maia, L.C.; Martinelli, G.; Menezes, M.; Morim, M.P.; Peixoto, A.L.; Pirani, J.R.; Prado, J.; Queiroz L.P.; Souza, S.; Souza, V.C.; Stehmann, J.R.; Sylvestre, L.S.; Walter, B.M.T. \& Zappi, D.C. 2012. New Brazilian Floristic List Highlights Conservation Challenges. BioScience 62: 39-45.

Forzza, R.C.; Costa, A.; Siqueira Filho, J.A.; Martinelli, G.; Monteiro, R.F.; Santos-Silva, F.; Saraiva, D.P.; Paixão-Souza, B.; Louzada, R.B. \& Versieux, L. 2014. Bromeliaceae. In: Lista de espécies da flora do 
Brasil. Jardim Botânico do Rio de Janeiro. Available at $<$ http://floradobrasil.jbrj.gov.br/jabot/floradobrasil/ FB5751>. Access on 8 June 2014.

Fraga, C.N.; Simonelli, M. \& Boudet Fernandes, H.Q. 2007. Metodologia utilizada na elaboração da lista da flora ameaçada de extinção no Estado do Espírito Santo. In: Simonelli, M. \& Fraga, C.N. (orgs.). Espécies da flora ameaçadas de extinção no estado do Espírito Santo. Ipema, Vitória. Pp. 59-72.

França, F. 2015. Vochysiaceae. In: Lista de Espécies da Flora do Brasil. Jardim Botânico do Rio de Janeiro. Available at <http://floradobrasil.jbrj.gov.br/jabot/ floradobrasil/FB250>. Access on 10 October 2015.

Gil, A.; Eggers, L.; Lovo, J. \& Chukr, N. 2015. Iridaceae. In: Lista de Espécies da Flora do Brasil. Jardim Botânico do Rio de Janeiro. Available at $<$ http:// floradobrasil.jbrj.gov.br/jabot/floradobrasil/FB136>. Access on 10 October 2015.

Giulietti, A.M.; Menezes, N.L.; Pirani, J.R.; Meguro, M. \& Wanderley, M.G.L. 1987. Flora da Serra do Cipó: caracterização e lista das espécies. Boletim de Botânica da Universidade de São Paulo 9: 1-151.

Giulietti, A.M.; Sano, P.T.; Costa, F.N.; Parra, L.R.; Echternacht, L.; Tissot-Squali, M.L.; Trovo, M.; Watanabe, M.T.C.; Hensold, N. \& Andrino, C. 2014. Eriocaulaceae. In: Lista de espécies da flora do Brasil. Jardim Botânico do Rio de Janeiro. Available at $<$ http://floradobrasil.jbrj.gov.br/jabot/floradobrasil/ FB7541>. Access on 18 June 2014.

Gomes-Klein, V.L.; Lima, L.F.P.; Gomes-Costa, G.A.; Medeiros, E.S. 2015. Cucurbitaceae. In: Lista de espécies da flora do Brasil. Jardim Botânico do Rio de Janeiro. Available at $<$ http://floradobrasil.jbrj. gov.br/jabot/floradobrasil/FB17036>. Access on 10 October 2015.

Harley, R.; França, F.; Santos, E.P.; Santos, J.S. \& Pastore, J.F. 2015. Lamiaceae. In: Lista de Espécies da Flora do Brasil. Jardim Botânico do Rio de Janeiro. Available at $<$ http://floradobrasil.jbrj.gov.br/jabot/ floradobrasil/FB132560>. Access on 10 October 2015.

IPEMA-Instituto de Pesquisas da Mata Atlântica. 2005. Conservação da Mata Atlântica no Espírito Santo: cobertura florestal e unidades de conservação. IPEMA, Conservação Internacional, Vitória. 142p.

Kirizawa, M.; Xifreda, C.C.; Couto, R. \& Araújo, D. 2015. Dioscoreaceae. In: Lista de Espécies da Flora do Brasil. Jardim Botânico do Rio de Janeiro. Available at $<$ http://floradobrasil.jbrj.gov.br/jabot/floradobrasil/ FB28614>. Access on 9 October 2015.

Koch, I.; Rapini, A.; Kinoshita, L.S.; Simões, A.O. \& Spina, A.P. 2014. Apocynaceae. In: Lista de espécies da flora do Brasil. Jardim Botânico do Rio de Janeiro. Available at $<$ http://floradobrasil.jbrj.gov.br/jabot/ floradobrasil/FB4532>. Access on 8 June 2014.

Leme, E.M.C. 1998. Canistropsis - Bromélias da Mata Atlântica. Salamandra, Rio de Janeiro. 143p.
Lima, H.C. de; Queiroz, L.P.; Morim, M.P.; Souza, V.C.; Dutra, V.F.; Bortoluzzi, R.L.C.; Iganci, J.R.V.; Fortunato, R.H.; Vaz, A.M.S.F.; Souza, E.R. de; Filardi, F.L.R.; Valls, J.F.M.; Garcia, F.C.P.; Fernandes, J.M.; Martins-da-Silva, R.C.V.; Perez, A.P.F.; Mansano, V.F.; Miotto, S.T.S.; Tozzi, A.M.G.A.; Meireles, J.E.; Lima, L.C.P. ; Oliveira, M.L.A.A.; Flores, A.S.; Torke, B.M.; Pinto, R.B.; Lewis, G.P.; Barros, M.J.F.; Schütz, R.; Pennington, T.; Klitgaard, B.B.; Rando, J.G.; Scalon, V.R.; Cardoso, D.B.O.S.; Costa, L.C. da; Silva, M.J. da; Moura, T.M.; Barros, L.A.V. de; Silva, M.C.R.; Queiroz, R.T.; Sartori, A.L.B.; Camargo, R. A.; Lima, I.B.; Costa, J.; Soares, M.V.B.; Snak, C.; São-Mateus, W.; Falcão, M.J.; Martins, M.V.; Reis, I.P. \& Cordula, E. 2015. Fabaceae. In: Lista de Espécies da Flora do Brasil. Jardim Botânico do Rio de Janeiro. Available at $<$ http://floradobrasil.jbrj.gov.br/jabot/floradobrasil/ FB136854>. Access on 10 October 2015.

Lista do Brasil. 2015. Lista de Espécies da Flora do Brasil. Jardim Botânico do Rio de Janeiro. Available at $<$ http://floradobrasil.jbrj.gov.br/>. Access on 18 April 2015.

Loeuille, B. \& Monge, M. 2014. Achyrocline. In: Lista de espécies da flora do Brasil. Jardim Botânico do Rio de Janeiro. Available at $<$ http://floradobrasil. jbrj.gov.br/jabot/floradobrasil/FB102956>. Access on 8 June 2014.

Lohmann, L.G. 2015. Bignoniaceae. In: Lista de Espécies da Flora do Brasil. Jardim Botânico do Rio de Janeiro. Available at $<$ http://floradobrasil.jbrj.gov. br/jabot/floradobrasil/FB112305>. Access on 10 October 2015.

Lombardi, J.A. 2014. Oleaceae. In: Lista de espécies da flora do Brasil. Jardim Botânico do Rio de Janeiro. Available at $<$ http://floradobrasil.jbrj.gov.br/jabot/ floradobrasil/FB10973>. Access on 28 June 2014.

Maas, P. \& Maas, H. 2014. Zingiberaceae. In:Lista de espécies da flora do Brasil. Jardim Botânico do Rio de Janeiro. Available at $<$ http://floradobrasil.jbrj. gov.br/jabot/floradobrasil/FB110726>. Access on 8 June 2014.

Mamede, M.C.H.; Sebastiani, R.; Almeida, R.F.; Francener, A. \& Amorim, A.M.A. 2015. Malpighiaceae. In: Lista de Espécies da Flora do Brasil. Jardim Botânico do Rio de Janeiro. Available at $<$ http://floradobrasil. jbrj.gov.br/jabot/floradobrasil/FB155>. Access on 10 October 2015.

Martinelli, G. \& Moraes, M.A. (orgs.). 2013. Livro vermelho da flora do Brasil. Andrea Jakobsson / Jardim Botânico do Rio de Janeiro, Rio de Janeiro. 1100 p.

Martinelli, G.; Vieira, C.M.; Gonzalez, M.; Leitman, P.; Piratininga, A.; Costa, A.F. \& Forzza, R.C. 2008. Bromeliaceae da Mata Atlântica brasileira: lista de espécies, distribuição e conservação. Rodriguésia 59: 209-258. 
Melo, E. de. 2014. Polygonaceae. In: Lista de espécies da flora do Brasil. Jardim Botânico do Rio de Janeiro. Available at $<$ http://floradobrasil.jbrj.gov.br/jabot/ floradobrasil/FB13718>. Access on 8 June 2014.

Mello-Silva, R. 2014. Velloziaceae. In: Lista de espécies da flora do Brasil. Jardim Botânico do Rio de Janeiro. Available at $<$ http://floradobrasil.jbrj.gov.br/jabot/ floradobrasil/FB15116>. Access on 8 June 2014.

Metzger, J. 2003. Como restaurar a conectividade de paisagens fragmentadas? In: Kageyama, P.; Oliveira, R.; Moraes, L.; Engel, V. \& Gandara, F. (orgs.). Restauração Ecológica de Ecossistemas Naturais. Fundação de Estudos e Pesquisas Agrícolas Florestais, Botucatu. Pp. 49-76.

Miranda, V.F.O.; Menezes, C.G.; Silva, S.R.; Díaz, Y.C.A. \& Rivadavia, F. 2014. Lentibulariaceae. In: Lista de espécies da flora do Brasil. Jardim Botânico do Rio de Janeiro. Available at <http://floradobrasil.jbrj. gov.br/jabot/floradobrasil/FB8570>. Access on 19 June 2014.

Mittermeier, R.A.; Gil, P.R. \& Hoffman, M. 2005. Hotspots revisited: Earth's biologically richest and most endangered terrestrial ecoregions. Conservation International, Washington. 392p.

Mittermeier, R.A.; Myers, N.; Robles-Gil, P. \& Mittermeier, C.G. 1999. Hotspots. Earth's biologically richest and most endangered terrestrial ecoregions. CEMEX/ Agrupacio'n Sierra Madre, Mexico City. 431p.

MMA. 2000. Avaliação e ações prioritárias para a conservação da biodiversidade da Mata Atlântica e Campos sulinos. MMA/SBF, Brasília. 40p.

Myers, N.; Mittermeier, R.A.; Mittermeier, C.G.; Fonseca, G.A.B. \& J. Kent. 2000. Biodiversity hotspots for conservation priorities. Nature 403: 853-858.

Pastore, J.F.; Ludtke, R. \& Ferreira, D.M.C. 2014. Polygalaceae. In: Lista de espécies da flora do Brasil. Jardim Botânico do Rio de Janeiro. Available at $<$ http://floradobrasil.jbrj.gov.br/jabot/floradobrasil/ FB20531>. Access on 8 June 2014.

Pabst, G.F.J. \& Dungs, F. 1977. Orchidaceae Brasilienses. Vol. 2. Brucke-Verlag Kurt Schmersow, Hildesheim. $418 \mathrm{p}$.

Peixoto, A.L. \& Gentry, A. 1990. Diversidade e composição florística da mata de tabuleiro na Reserva Florestal de Linhares (Espírito Santo, Brasil). Revista Brasileira de Botânica 13: 19-25.

Pereira, O.J. 2007. A cobertura vegetal do Espírito Santo. In: Simonelli, M. \& Fraga, C.N. (orgs.). Espécies da Flora ameaçadas de extinção no Estado do Espírito Santo. Ipema, Vitória. Pp. 17-20.

Pereira, O.J. \& Assis, A.M. 2000. Florística da restinga de Camburi. Acta Botanica Brasilica 14: 99-111.

Pereira, O.J.; Assis, A.M. \& Souza, R.L.D. 1998. Vegetação da restinga de Pontal do Ipiranga, Município de Linhares (ES). In: Watanabe, S. (coord.). Anais do IV Simpósio de Ecossistemas Brasileiros. Aciesp, São Paulo. Pp. 117-128.
Pereira, O.J. \& Zambom, O. 1998. Composição florística da restinga de Interlagos, Vila Velha (ES). In: Watanabe, S. (coord.). Anais do IV Simpósio de Ecossistemas Brasileiros. Aciesp, São Paulo. Pp. 129-139.

Peterle, P.L.; Chagas, A.P.; Thomaz, L.D.; Dutra, V.F. \& Valadares, R.T.. Mimosoideae (Leguminosae) do Parque Estadual Paulo César Vinha, Espírito Santo, Brasil. Rodriguésia 66: 245-257.

Pirani, J.R. \& Groppo, M. 2015. Rutaceae. In: Lista de Espécies da Flora do Brasil. Jardim Botânico do Rio de Janeiro. Available at $<\mathrm{http}$ ://floradobrasil.jbrj.gov. br/jabot/floradobrasil/FB212>. Access on 11 October 2015.

Pirani, J.R.; Mello-Silva, R. \& Giulietti, A.M. 2003. Flora de Grão-Mogol, Minas Gerais, Brasil. Boletim de Botânica da Universidade de São Paulo 21:1-24.

Prance, G.T. 1982. Forest refuges: evidence from woody angiosperms. In: Prance, G.T. (ed.). Biological diversification in the tropics. Columbia University Press, New York. Pp. 137-158.

Profice, S.R.; Kameyama, C.; Côrtes, A.L.A.; Braz, D.M.; Indriunas, A.; Vilar, T.; Pessoa, C.; Ezcurra, C. \& Wasshausen, D. 2014. Acanthaceae. In: Lista de espécies da flora do Brasil. Jardim Botânico do Rio de Janeiro. Available at <http://floradobrasil.jbrj.gov.br/ jabot/floradobrasil/FB109949>. Access on 8 June 2014.

Quinet, A.; Baitello, J.B.; Moraes, P.L.R. de; Assis, L. \& Alves, F.M. 2015. Lauraceae. In: Lista de espécies da flora do Brasil. Jardim Botânico do Rio de Janeiro. Available at $<$ http://floradobrasil.jbrj.gov.br/jabot/ floradobrasil/FB30189>. Access on 11 October 2015.

Ribeiro, J.E.L.S.; Hopkins, M.J.G.; Vicentini, A.; Sothers, C.A.; Costa, M.A.S.; Brito, J.M.; Souza, M.A.D.; Martins, L.H.P.; Lohmann, L.G.; Assunção, P.A.C.L.; Pereira, E.C.; Silva, C.F.; Mesquita, M.R. \& Procópio, L.C. 1999. Flora da Reserva Ducke: Guia de Identificação das plantas vasculares de uma floresta de terra-firme na Amazônia Central. INPA, Manaus. 799p.

Romaniuc Neto, S.; Carauta, J.P.P.; Vianna Filho, M.D.M.; Pereira, R.A.S.; Ribeiro, J.E.L. da S.; Machado, A.F.P.; Santos, A. dos; Pelissari, G. \& Pederneiras, L.C. 2015. Moraceae. In: Lista de espécies da flora do Brasil. Jardim Botânico do Rio de Janeiro. Available at <http:// floradobrasil.jbrj.gov.br/jabot/floradobrasil/FB19779>. Access on 12 October 2015.

Romaniuc Neto, S. \& Gaglioti, A.L. 2015. Urticaceae. In: Lista de Espécies da Flora do Brasil. Jardim Botânico do Rio de Janeiro. Available at $<$ http://floradobrasil. jbrj.gov.br/jabot/floradobrasil/FB243>. Access on 11 October 2015.

Ruschi, A. 1970. Orchidáceas do Estado do Espírito Santo: algumas espéceis ornamentais; com várias novas variedades dos gêneros Laelia; Cattleya e Oncidium. Boletim do Museu de Biologia Prof. Mello Leitão, Série Botânica 51A: 1-16.

Sá, C.F.C. 2014. Nyctaginaceae. In: Lista de espécies da flora do Brasil. Jardim Botânico do Rio de Janeiro. 
Available at $<$ http://floradobrasil.jbrj.gov.br/jabot/ floradobrasil/FB10909>. Access on 28 June 2014.

Saiter, F.Z. \& Thomaz, L.D. 2014. Revisão da lista de espécies arbóreas do inventário de Thomaz \& Monteiro (1997) na Estação Biológica de Santa Lúcia: o mais importante estudo fitossociológico em florestas montanas do Espírito Santo. Boletim do Museu de Biologia Mello Leitão 34: 101-128.

Sarnaglia Junior, V.B.; Thomaz, L.D. \& Guimarães, E.F. 2014. O gênero Peperomia Ruiz \& Pav. na Área de Proteção Ambiental do Mestre Álvaro, Espírito Santo, Brasil. Boletim do Museu de Biologia Mello Leitão 35: 21-34.

Sano, P.T.; Giulietti, A.M.; Costa, F.N.; Trovo, M.; Echternacht, L.; Tissot-Squalli, M.L.; Watanabe, M.T.C.; Hensold, N.; Andrino, C.O. \& Parra, L.R. 2015. Eriocaulaceae. In: Lista de Espécies da Flora do Brasil. Jardim Botânico do Rio de Janeiro. Available at $<$ http://floradobrasil.jbrj.gov.br/jabot/ floradobrasil/FB7548> . Access on 9 October 2015.

Secco, R.; Cordeiro, I. \& Martins, E.R. 2014. Phyllanthaceae. In: Lista de espécies da flora do Brasil. Jardim Botânico do Rio de Janeiro. Available at $<$ http://floradobrasil.jbrj.gov.br/jabot/ floradobrasil/FB24166>. Access on 8 June 2014.

Simpson, B. 2014. Krameriaceae. In: Lista de espécies da flora do Brasil. Jardim Botânico do Rio de Janeiro. Available at $<$ http://floradobrasil.jbrj.gov.br/jabot/ floradobrasil/FB140>. Access on 19 June 2014.

Sobral, M. 2014. Musaceae. In: Lista de espécies da flora do Brasil. Jardim Botânico do Rio de Janeiro. Available at $<\mathrm{http}$ ://floradobrasil.jbrj.gov.br/jabot/ floradobrasil/FB85800>. Access on 28 June 2014.

Sobral, M.; Proença, C.; Souza, M.; Mazine, F. \& Lucas, E. 2014. Myrtaceae. In: Lista de espécies da flora do Brasil. Jardim Botânico do Rio de Janeiro. Available at $<$ http://floradobrasil.jbrj.gov.br/jabot/ floradobrasil/FB10275>. Access on 28 June 2014.

Somner, G.V.; Ferrucci, M.S.; Acevedo-Rodríguez, P.; Perdiz, R.O.; Coelho, R.L.G. \& Medeiros, H. 2015. Sapindaceae. In: Lista de espécies da flora do Brasil. Jardim Botânico do Rio de Janeiro. Available at $<$ http://floradobrasil.jbrj.gov.br/jabot/floradobrasil/ FB2016>. Access on 10 October 2015.

Souza, V.C. \& Hassemer, G. 2015. Plantaginaceae. In: Lista de Espécies da Flora do Brasil. Jardim Botânico do Rio de Janeiro. Available at $<$ http://floradobrasil. jbrj.gov.br/jabot/floradobrasi1/FB191>. Access on 11 October 2015.

Standley, P.C. 1930. Rubiaceae. In: Dahlgren, B.E. (ed.). Studies of american plants VI. Field Museum of Natural History, Botanical series 8: 151-236.
Stefano, M.V.; Calazans, L.S.B. \& Sakuragui, C.M. 2014. Meliaceae. In: Lista de espécies da flora do Brasil. Jardim Botânico do Rio de Janeiro. Available at <http://floradobrasil.jbrj.gov.br/jabot/ floradobrasil/FB19740>. Access on 28 June 2014.

Stehmann, J.R.; Forzza, R.C.; Salino, A.; Sobral, M.; Costa, D.P. \& Kamino, L.H.Y. 2009. Plantas da Floresta Atlântica. Jardim Botânico do Rio de Janeiro, Rio de Janeiro. 516p.

Stehmann, J.R.; Mentz, L.A.; Agra, M.F.; VignoliSilva, M.; Giacomin, L. \& Rodrigues, I.M.C. 2015. Solanaceae. In: Lista de Espécies da Flora do Brasil. Jardim Botânico do Rio de Janeiro. Available at <http://floradobrasil.jbrj.gov.br/jabot/ floradobrasil/FB225>. Access on 10 October 2015.

Tabarelli, M.; Silva, J. \& Gascon, C. 2004. Tropical forest fragmentation, synergisms and the impoverishment of neotropical forests. Biodiversity and Conservation 13: 1419-1425.

Taylor, N.; Santos, M.R.; Larocca, J. \& Zappi, D. 2014. Cactaceae. In: Lista de espécies da flora do Brasil. Jardim Botânico do Rio de Janeiro. Available at $<$ http://floradobrasil.jbrj.gov.br/jabot/ floradobrasil/FB1733>. Access on 8 June 2014.

Thiers, B. [continuously updated]. Index Herbariorum: A global directory of public herbaria and associated staff. New York Botanical Garden's Virtual Herbarium. Available at $<\mathrm{http}: / /$ sweetgum.nybg. org/ih/>. Access on 5 May 2014.

Walter, B.M.T. 2014. Hydroleaceae. In: Lista de espécies da flora do Brasil. Jardim Botânico do Rio de Janeiro. Available at $<$ http://floradobrasil. jbrj.gov.br/jabot/floradobrasil/FB132>. Access on 19 June 2014.

Wanderley, M.G.L.; Shepherd, G.J.; Martins, S.E.; Estrada, T.E.M.D.; Romanini, R.P.; Koch, I.; Pirani, J.R.; Melhem, T.S.; Harley, A.M.G.; Kinoshita, L.S.; Magenta, M.A.G.; LonghiWagner, H.M.; Barros, F.; Lohmann, L.G.; Amaral, M.C.E.; Cordeiro, I.; Aragaki, S.; Bianchini, R.S. \& Esteves, G.L. 2011. Checklist das Spermatophyta do Estado de São Paulo, Brasil. Biota Neotropica 11: 191-388.

Zappi, D. 2015. Crassulaceae. In: Lista de Espécies da Flora do Brasil. Jardim Botânico do Rio de Janeiro. Available at <http://floradobrasil.jbrj.gov.br/jabot/ floradobrasil/FB95>. Access on 10 October 2015.

Zappi, D.; Guimarães, E.F.; Manoel, E.A. \& Siqueira, C.E. 2014. Loganiaceae. In: Lista de espécies da flora do Brasil. Jardim Botânico do Rio de Janeiro. Available at $<$ http://floradobrasil.jbrj.gov.br/jabot/ floradobrasil/FB8663>. Access on 19 June 2014. 